\title{
West Moesian uplifted hydrogeological system
}

\author{
Viktor Spasov ${ }^{l}$ \\ ${ }^{1}$ Geological Institute, Bulgarian Academy of Sciences, 1113 Sofia, Bulgaria; \\ e-mail: viktorspasov@abv.bg
}

\section{Западно-Мизийска издигната хидрогеоложка система}

\section{Виктор Спасов}

Spasov, V. 2020. West Moesian uplifted hydrogeological system. Engineering Geology and Hydrogeology, 34, 29-44.

\begin{abstract}
A comprehensive analysis of the hydrogeological conditions in the westernmost part of the Bulgarian Danube Plain is presented. During the Neogene and Quaternary period this area is subjected to continuous uplift. As a result, river valleys are deeply incised into the terrain and all shallow aquifers are well drained in the hydrological network. This process determines the specific regime and dynamics of the groundwater, characteristic of the identified West Moesian uplifted hydrogeological system.

The Quaternary aquifer is the most abundant in the system. It is formed in four riparian lowlands - two along the Timok River (Bregovska and Baley-Kudelin) and two along the Danube River (Novoselska and Vidin Lowlands) (Figs 1, 7,8). The hydraulic properties of the aquifer are very good: Transmissivity $T=800-1000 \mathrm{~m}^{2} / \mathrm{d}$ and hydraulic conductivity $K=60-80 \mathrm{~m} / \mathrm{d}$. Several Ranney water collector wells extracting up to $140 \mathrm{~L} / \mathrm{s}$ have been built in the Vidin lowland. Potential groundwater resources in this lowland are estimated at about $14 \mathrm{~m}^{3} / \mathrm{s}$, with $13 \mathrm{~m}^{3} / \mathrm{s}$ being infiltrated from the Danube River. Second in importance in the hydrogeological system is the Sarmatian aquifer. It consists of two layers: upper - limestone and lower - sandy limestone (Figs 2 and 3). The waters are used for local water supply by capturing karst springs. The results of monitoring observations on the chemical composition of groundwater during the period 1980-1991 are presented in diagrams (Figs 4, 5, 6, 9, 11, 12,13). Groundwater, being the only water source in the area, must be carefully protected from industrial and agricultural pollution.
\end{abstract}

Keywords: Hydrogeological systems, Moesian platform, Danube River riparian plains, Sarmatian aquifer, groundwater resources.

Резюме. Представен е подробен анализ на хидрогеоложките условия в най-западната част на Дунавската равнина. Този район е подложен на непрекъснато издигане през Неогена и Кватернера. В резултат на това, речните долини са дълбоко врязани в терена и плитко залягащите водоносни хоризонти се дренират в хидрографската мрежа. Идентификацията на Западно-Мизийската издигната хидрогеоложка система се основова на формирания специфичен режим и динамика на подземните води.

Кватернерният водоносен хоризонт е най-водообилният в системата. Той е формиран в четири крайречни низини: две по брега на р. Тимок (Бреговска и Балей-Куделин) и две край р. Дунав (Новоселска и Видинска) (фиг. 1, 7, 8). Филтрационните свойства на водоноса са много добри: проводимост $T=800-1000 \mathrm{~m}^{2} / \mathrm{d}$ и коефициент на филтрация $K=60-80 \mathrm{~m} / \mathrm{d}$. 
Във Видинската низина са изградени няколко високодебитни кладенци тип „раней”, даващи дебит до $140 \mathrm{dm}^{3} / \mathrm{s}$. Потенциалните експлоатационни ресурси в тази низина се оценяват на $14 \mathrm{~m}^{3} / \mathrm{s}$, от които $13 \mathrm{~m}^{3} / \mathrm{s}$ са привлекаеми от реката. Втори по значение в хидрогеоложката система е сарматският водоносен хоризонт. Той се състои от два пласта: горен - варовиков и долен - песъчливо варовит (фиг. 2 и 3). Водите се използват за локално водоснабдяване чрез каптиране на карстови извори. Резултатите от мониторинговите наблюдения за химическия състав на подземните води през периода 1980-1991 г. са представени в подходящи диаграми (фиг. $4,5,6,9,11,12,13)$. Подземните води, бидейки единствения воден източник в района, трябва да бъдат надеждно опазвани срещу индустриално и селско-стопанско замърсяване.

Ключови думи: подземни води, минерални води, геотермални ресурси, геотермия.

\section{Въведение}

В основни хидрогеоложки монографии, като Хидрогеоложко райониране на България (Antonov et al., 1962), Подземни води в България (Antonov, Danchev, 1980), Подземные воды Северной Болгарии (Yovchev, Ryzhova, 1962) и др., Видинския район се включваше в рамките на Ломската депресия. Тази вече остаряла представа за гео-структурния строеж и хидрогеоложки условия във Видинския район, както и множеството нови данни от многостранни проучвания, извършени през последните 40 - 50 години, ни дадоха основание за идентифициране на представената тук самостоятелна хидрогеоложка структурна единица. От друга страна, седиментите с меотска и понтска възраств С.З. България, до въвеждането на лито-стратиграфските единици се отнасяха към Плиоцена. Формираните в тях водоносни тела също се определяха като плиоценски. Сега свитите, обхващащи тези отложения, както и съответните хидрогеоложки единици, се отнасят към Миоцена, а Плиоцен във Видин - Кулския район почти не се отбелязва. Необходимо е и уточняване на пространствените и хидравлични взаимоотношения на водоносните тела в представяната хидрогеоложка система, която се характеризира със собствен режим и динамика на подземните води, коренно различни от тези в съседния Ломски артезиански басейн.

\section{Хидрогеоложки условия}

Западно-Мизийската издигната хидрогеоложка система географски обхваща найзападния район на Дунавската равнина - от границата с Република Сърбия до долината на р. Арчар. Нейното отделяне в самостоятелна хидрогеоложка система се основава на геолого-структурния строеж и характерните хидрогеоложки условия в тази част на Мизийската платформа. В тектонско отношение тя попада в очертанията на така наречения Видинско - Пленишки вал, който се простира и на Румънска територия. На изток системата граничи с Ломската депресия (вододела между реките Видбол и Арчар), на юг - с Предбалкана, а на запад достига до долината на р. Тимок и границата с Република Сьрбия. На хидрогеоложката карта (фиг. 1) са представени основните хидрогеоложки единици. Тя е комбинирана, като с растери и цветове и чрез прозрачност са показани първите и вторите по залягане водоносни тела.

Геоложкият строеж и геоморфоложките форми свидетелстват за непрекъснатото издигане на тези земи през Плиоцена и Кватернера. Реките, идващи от Стара планина, ерозират и разсичат с долините си цялата неогенска седиментна серия. Вследствие на това водоносните тела се дренират или пряко в речната мрежа или чрез извори по склоновете на речните долини (фиг. 2 и 3 ).

\section{Хидрогеоложки структурни единици}

В зоната на активния водообмен са формирани четири водоносни хоризонта:

- Алувиален водоносен хоризонт на р. Дунав;

- Плейстоценски водоносен комплекс; 
- Понтски водоносен хоризонт;

- Сарматски водоносен хоризонт

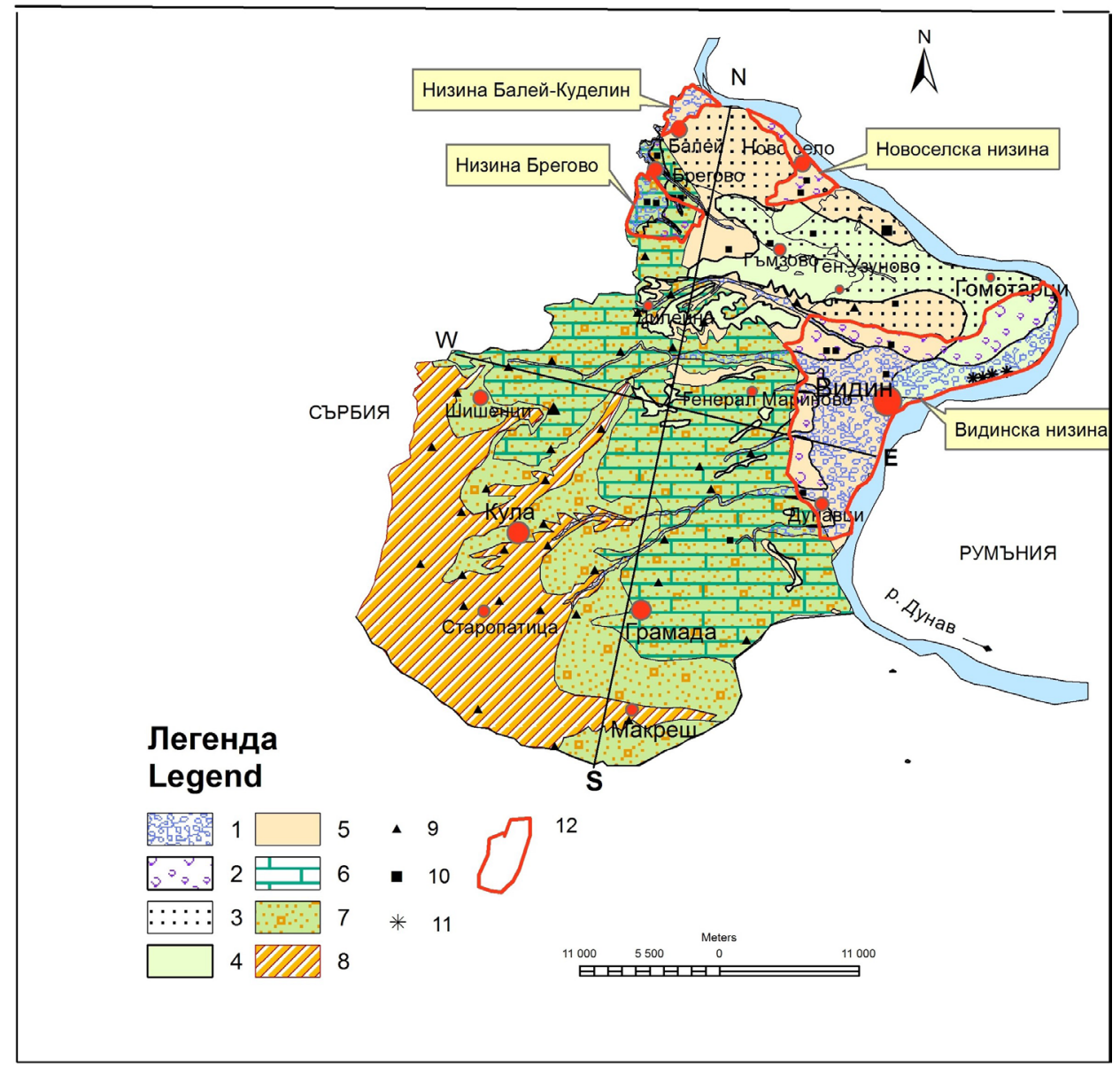

Фиг. 1. Хидрогеоложка карта на Западно-Мизийската издигната водоносна система

1-2 - (aQh) Алувиален водоносен хоризонт (първа и втора речни тераси); 3 - (e,prQp $\left.{ }^{2-1}\right)$ Плейстоценски водоносен комплекс (льос и старокватернерни чакъли); $4-\left(\operatorname{arN1} 1^{\mathrm{p}}\right)$ Понтски песъчлив водоносен хоризонт; $5-\left(\mathrm{smN1}{ }^{\mathrm{m}-\mathrm{p}}\right)$ Меотски глинест непродуктивен комплекс; $6-\left(\mathrm{fuN} 1^{\mathrm{s}}\right)$ Сарматски горен, варовиков водоносен хоризонт; $7-\left(\mathrm{dmN} 1^{\mathrm{s}}\right)$ Сарматски долен, песъчливо-варовит водоносен хоризонт; 8 - Кулска пукнатинна водоносна зона; 9 - извори; 10 - шахтови кладенци; 11 - кладенци тип «Раней»; 12 - Очертания на крайречните низини;

Fig. 1. Map of the West-Moesian uplifted hydrogeological system

1-2 - (aQh) Alluvial aquifer (first and second river-plain terraces); 3 - (e,prQp ${ }^{2-1}$ ) Pleistocene aquifer (loess and early quaternary gravels $) ; 4-\left(\operatorname{arN1} 1^{\mathrm{p}}\right)$ Pontian sandy aquifer; $5-\left(\mathrm{smN} 1^{\mathrm{m}-\mathrm{p}}\right)$ Meotian clayey nonproductive complex; $6-\left(\right.$ fuN1 $\left.1^{\mathrm{s}}\right)$ Upper Sarmatian calcareous aquifer; $7-\left(\mathrm{dmN} 1^{\mathrm{s}}\right)$ Lower Sarmatidn sandy-calcareous aquifer; 8 - Fissure water zone Kula; 9 - springs; 10 - large diameter water wells; 11 - collector wells; 12 - Boundaries of the riveraine lowlands. 


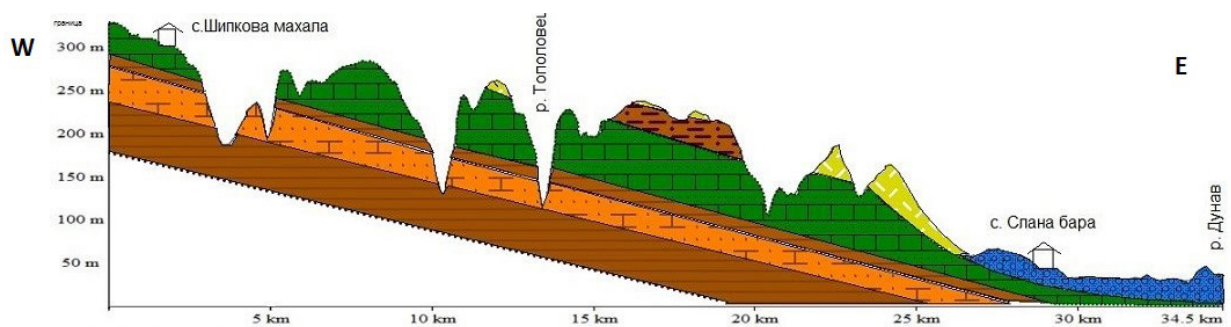

ЛЕГЕНДА

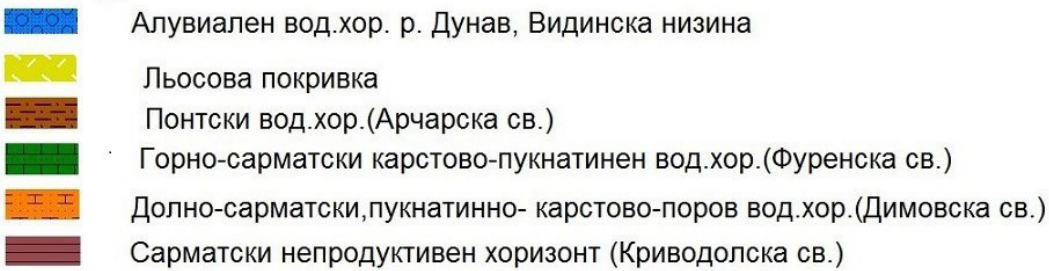

Фиг. 2. Схематичен профил (W - E) през Западно-Мизийската издигната хидрогеоложка система Fig. 2. Schematic cross-section (W - E) across the West-Moesian uplifted hydrogeological system LEGEND: Alluvial aquifer; Loess cover; Pontian aquifer; Upper Sarmatian aquifer; Lower Sarmatian aquifer; Sarmatian aquiclude

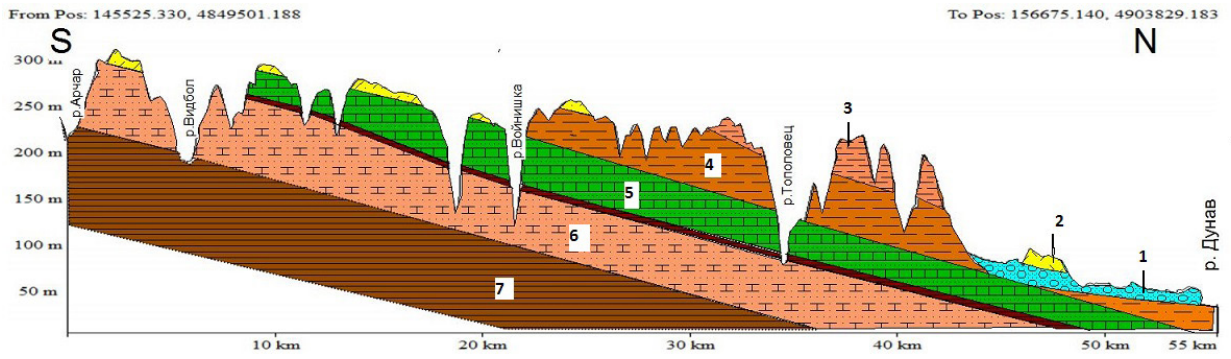

Фиг. 3. Схематичен профил ( $\mathrm{S}$ - N ) през Западно-Мизийската издигната хидрогеоложка система 1 - алувиален водоносен хоризонт (Видинска низина); 2 - льосова покривка;

3 - понтски водоносен хоризонт (Арчарска свита); 4 - меотски водоупор (Смирненска свита); 5 - горен сарматски водоносен хоризонт (Фуренска свита); 6 - долен сарматски водоносен хоризонт (Димовска свита); 7 - сарматски водоупор (Криводолска свита)

(Вертикалният мащаб на профилите е силно преувеличен, за да се открои ерозирания релеф и дрениращата роля на речните долини.)

Fig. 3. Schematic cross-section $(\mathrm{S}-\mathrm{N})$ across the West-Moesian uplifted hydrogeological system

1 - alluvial aquifer (Vidin lowland); 2 - loess cover; 3 - Pontian aquifer (Achar Formation); 4 - Meotian aquiclude (Smirnenski Formation); 5 - Upper Sarmatian aquifer (Furenska Formation); 6 - Lower Sarmatian aquifer (Dimovska Formation); 7 - Sarmatian aquiclude (Krivodol Formation)

(The vertical scale is strongly exaggerated in order to point out the eroded relief and the drainage role of rivers).

\section{1. Кватернерни водоносни тела}

1.1. Алувиален водоносен хоризонт.

Алувиалният водоносен хоризонт е най-водообилният в Западно-Мизийската хидрогеоложка система. Той е разпространен предимно в крайдунавските низини. Тук, а и въобще навсякъде по дунавското крайбрежие, към крайречните низини следва да се включват само заливната и първа надзаливна речни тераси, 
образувани през Холоцена. Динамиката и режимът на подземните води в тези низини се диктуват от водните стоежи на реката, които имат голяма сезонна амплитуда (до $5-6 \mathrm{~m}$ ). В по-високите тераси нивата на подземните води не се влияят пряко от нивото на реката. Въпреки че са изградени от алувиални материали, от хидрогеоложка гледна точка те не трябва да се включват в рамките на крайречните низини, защото нямат хидравлично взаимодействие с р. Дунав.

Досега, в хидрогеоложката литература и в управленските нормативни документи на басейновите дирекции, като най-западна крайдунавска низина се определяше „Брегово-Новоселската низина” (Antonov, Danchev, 1980), (Пенчев и др., 1999 $\left.\phi^{1}\right)$, (Басейнова дирекция Дунавски район - подземно водно тяло BG1G0000Qal001). В нейната площ влизаха земите по периметъра от гр. Брегово по р. Тимок до устието, оттам по р. Дунав до с. Ново село и обратно по паралела до Брегово. Тази хидрогеоложка единица, определяна като единно водоносно тяло, обаче подлежи на ревизия.

В най-западна част на Дунавската равнина, в края на Вилафранка се отлагат така наречените от СТ. Бончев «плоскогорни чакъли» с дебелина до 15 m (Jaranoff, 1961). Над тях, от началото на средния Плейстоцен (0,78 Ма ВР) започва образуването на льосовия еоличен комплекс, който ще достигне дебелина до 25 m (Evlogiev, 2006). В онези времена р. Дунав все още не съществува. Едва по-късно, към края на средния Плейстоцен, по време на миндел - рицката междуледникова епоха, преди около 300000 години, става преливане на водите от Панонския басейн към Предкарпатския (Дакийски) басейн и възниква Палеодунавската долина (Baltakov, 2005). Първоначално руслото на р. Дунав се е разполагало на север от сегашното му положение. Постепенно речното корито се е измествало на юг, ерозирайки плейстоценските и отдолу лежащите миоценски седименти. Така, в българския участък между устието на р. Тимок и с. Ново село, вследствие ерозията нямаме крайбрежна заливаема речна тераса. При Ново село е образувана едноименната низина, като пьрва надзаливна тераса, а по-надолу по течението реката размива сарматски седименти. Следователно, в територията, която се приемаше като «Брегово-Новоселска низина», всъщност са формирани четири отделни хидрогеоложки единици: две крайбрежни низини на р. ТимокБреговска и Балей-Куделин, една крайдунавска - Новоселската и разположения между тях плейстоценски водоносен комплекс (фиг. 1).

\subsection{1. Низина Брегово}

Бреговската низина в действителност не би трябвало да се разглежда като същинска крайдунавска низина, защото е твърде отдалечена от Дунава. Разположена е на $16 \mathrm{~km}$ нагоре по течението на р. Тимок. Участькът от р. Тимок, който е западна граница на низината, се явява също и държавна граница между България и Сърбия. Бреговската низина обхваща заливната и първа надзаливна тераса на р. Тимок и е с площ от около $12,5 \mathrm{~km}^{2}$. Тя има двуслоен строеж: долен чакълесто песъчлив пласт с дебелина $7-16 \mathrm{~m}$, и горен - глинесто песъчлив слой 2 - 10 m. Филтрационните свойства на долния пласт са много добри $(K=80 \div 100$ $\mathrm{m} / \mathrm{d})$. Град Брегово е застроен на границата между заливната и пьрва надзаливна тераса на р. Тимок. Той се водоснабдява с подземни води от заливната тераса (ПС №3). Чрез шахтови и тръбни кладенци могат да се добиват подземни води и от по-високо разположения плейстоценски водоносен комплекс в междуречието p. Тимок - p. Делейнска - p. Дунав, но там водното ниво е сравнително дълбоко - повече от $20 \mathrm{~m}$ от повърхността.

${ }^{1}$ Пенчев, П., Гюров, Ч., Стоянов, Н., Петров, В. 1999. Съставяне на карта на подземните води в Република България в М 1:500 000 с обяснителна записка. МОСВ - Дог. №10/99, ХИДРОКОМП ООД, София. 
Режимът и подхранването на подземните води в низината се обуславя от водните стоежи на р. Тимок, от инфилтрацията на валежни води и приток от сарматския водоносен хоризонт по ската и през подложката на низината. Самата низина има своя водосборна област от около $70 \mathrm{~km}^{2}$. Тя е защитена с крайречна брегова дига. При интензивно пролетно снеготопене и интензивни валежи в низината се втичат значителни обеми повърхностни и подземни води. Поради наличието на крайбрежна дига и липсата на отводнителна система, те не могат да се оттекат в реката и предизвикват системно пролетно наводняване на заливната тераса и ниско разположените сгради на гр. Брегово. През някои години се стига до обявяване на „бедствено положение”, както напр. през м. февруари 2010 г. и на 10-13 март 2018 г.

Химическият състав на подземната вода се следи в мониторинговия пункт 101/ I-1 от Националната опорна хидрогеоложка и хидрохимична мрежа тръбен кладенец гр. Брегово (Tsankov et al., 1993). Изследват се водни проби 1 път годишно. Осреднените резултати от 6 опробвания през периода 1980 - 1991 г. са представени на (фиг. 4 ). Водата се определя като хидрокарбонатно-калциевомагнезиева, твърда $(8,29 \mathrm{meq} / \mathrm{l})$, годна за питейно-битови нужди.
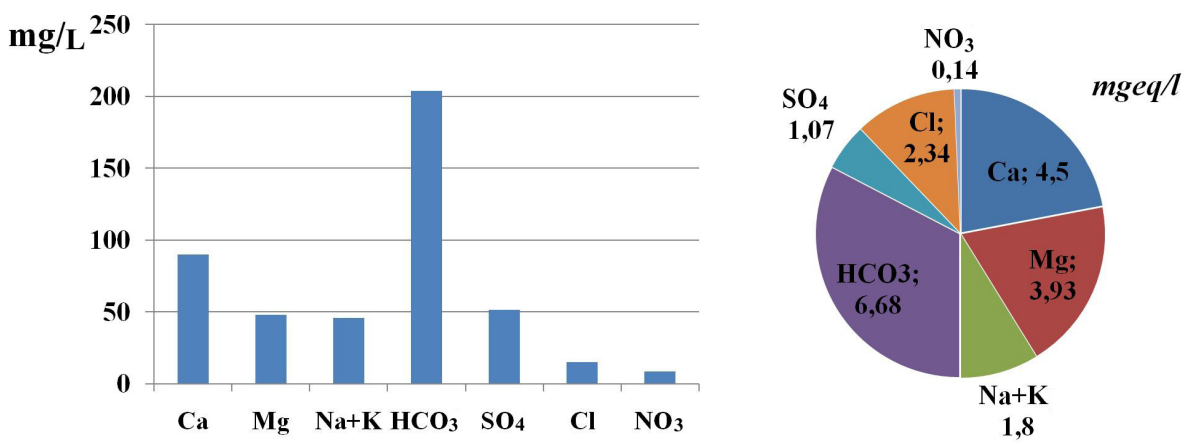

Фиг. 4. Химически състав на подземната вода в низина Брегово

Fig. 4. Chemical composition of groundwater in Bregovo lowland

В мониторинговия пункт ШК1-ПС Брегово 3 на Басейнова дирекция Дунавски район (БДДР), намиращ се в заливната тераса на p. Тимок, се наблюдават повишени концентрации, над стандарта за качество по показателя за нитрати (фиг. 5).

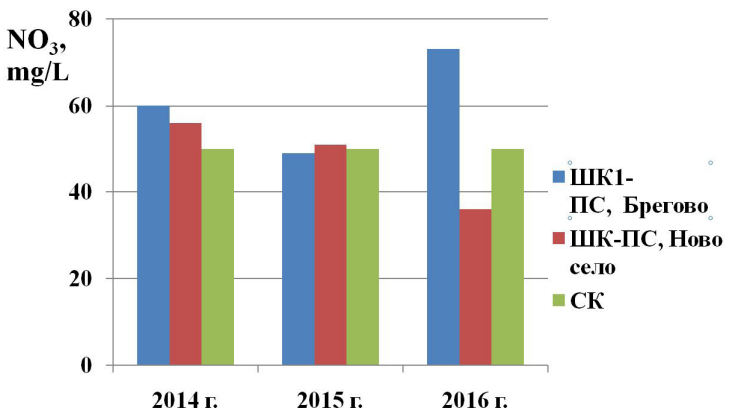

Фиг. 5. Съдържание на нитрати $\left(\mathrm{NO}_{3}\right)$ в низина Брегово и низина Ново село (CK $\mathrm{mg} / \mathrm{L}$ - стандарт за качество) Fig. 5 Nitrate $\left(\mathrm{NO}_{3}\right)$ content in the water of Bregovo and Novo Selo lowlands 
При изследване на обработваемите почви край Брегово, с. Ракитица и с. Балей - Куделин е установено, че над 50 \% от тях съдържат наднормени концентрации на мед, цинк, олово и сяра, вследствие напояването с речни води, които са замърсени от медодобивното находище «Мини Бор» на сръбска територия. Съществува риск от потенциално замърсяване на подпочвените води чрез натрупаните във времето отлагания на тежки метали по поречието на р. Тимок. При евентуална засилена експлоатация на алувиалния водоносен хоризонт, в близост до реката, има опасност от привличане на замърсени със сулфати и тежки метали речни води.

\subsection{2. Низина Балей-Куделин}

Низината е изградена от сравнително малките по размер, заливна и надзаливна тераси на десния бряг на р. Тимок, непосредствено преди вливането иे в р. Дунав (фиг. 1). Нейната площ е само 5,6 km². Подобно на Бреговската низина и тук заливната тераса има двуслоен строеж - долен силно пропусклив чакълестопесъчлив слой и горен, слабо пропусклив песъчливо-глинест слой. Низината е защитена срещу повърхностно заливане с крайбрежна дига. В низината е изградена канална отводнителна система за снижаване на нивото на подземните води при високи водни стоежи в р. Дунав. Химическото състояние на подземните води е лошо поради повишено съдържание на нитрати. Селата Балей и Куделин са разположени на границата между заливната и първа надзаливна тераси. Те се водоснабдявят от ПС при с. Връв, която се намира в близката Новоселска низина.

\subsection{3. Новоселска низина}

Същинската Новоселска низина заема крайбрежието на р. Дунав между с. Връв и Ново село (фиг. 1). Тя обхваща първа надзаливна речна тераса с относителна височина 10-15 т спрямо нивото на реката, а заливна тераса изобщо липсва. В тези очертания нейната площ възлиза на около $15 \mathrm{~km}^{2}$. Алувиалният водоносен хоризонт има двуслоен строеж - долен чакълесто песъчлив пласт с дебелина 10-15 m и с много добри филтрационни свойства $(K=60-80 \mathrm{~m} / \mathrm{d}, \mathrm{T}=$ 800-1000 m²/d), и с относителен дебит на тръбни кладенци $q=12 \mathrm{l} / \mathrm{s} / \mathrm{m}$. Горният глинесто-песъчлив слой е с дебелина 5-10 m, като в него се установява водното ниво. С води от ПС с. Връв се водоснабдяват селата Връв, Балей и Куделин. Химическият състав на подземната вода се следи в мониторинговия пункт 102/ I-2 от Националната опорна хидрогеоложка и хидрохимична мрежа - тръбен кладенец - с. Ново село (Tsankov et al., 1993). Осреднените резултати от 11 опробвания през периода 1980 - 1991 г. са представени на (фиг. 6). Водата се характеризира като хидрокарбонатно-калциево-магнезиева, средно твърда (7,5 $\mathrm{meq} / \mathrm{l})$, годна за питейно-битово потреблиние.
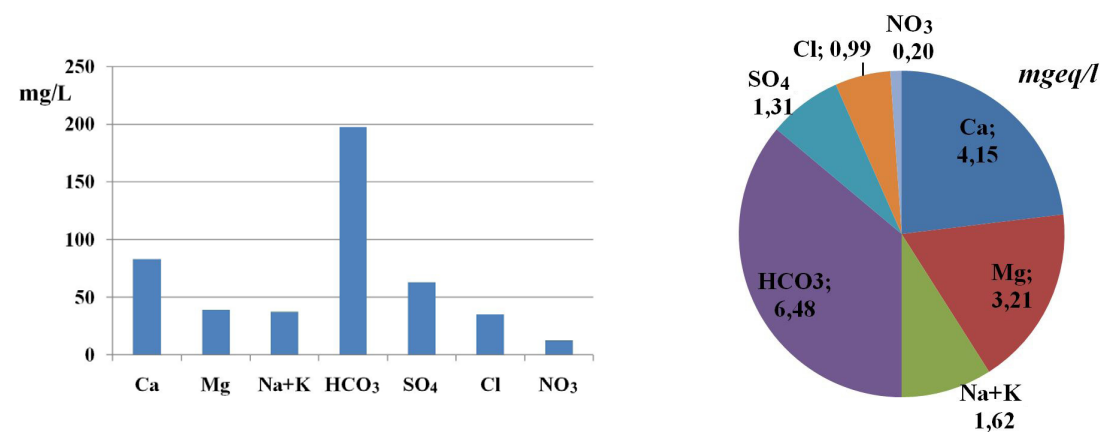

Фиг. 6. Химически състав на подземната вода в Новоселската крайдунавска низина

Fig. 6. Groundwater chemical composition in Novo Selo lowland 


\subsection{4. Видинска низина}

Видинската низина започва северно от с. Сланотрън и на юг се простира до с. Дунавци (фиг. 1). Низината е защитена от наводнения с предпазна дига. При пролетните пълноводия р. Дунав покачва нивото си до 5 - $6 \mathrm{~m}$. За предпазване от подземно оводняване и за поддържане на добро мелиоративно състояние на земеделските земи в низината е изградена канална отводнителна система. Площта на ниската част е около $120 \mathrm{~km}^{2}$.

Алувиалният водоносен хоризонт има двуслоен строеж (фиг. 8). Долният чакълесто-песъчлив пласт е със средна дебелина $14 \mathrm{~m}$. Той е силно проницаем с параметри: коефициент на филтрация $K=60 \div 80 \mathrm{~m} / \mathrm{d}$, проводимост $\mathrm{T}=$ $800 \div 1000 \mathrm{~m}^{2} / \mathrm{d}$ и коефициент на нивопредаване $15000 \div 20000 \mathrm{~m}^{2} / \mathrm{d}$. Горният глинесто-песъчлив слой е с дебелина 5 до $10 \mathrm{~m}$ и е слабо пропусклив $K=1 \div 3$ $\mathrm{m} / \mathrm{d}$. В района на гр. Видин дебелината на чакълесто песъчливия пласт намалява до 6-7 $\mathrm{m}$ и $K=70 \mathrm{~m} / \mathrm{d}$.

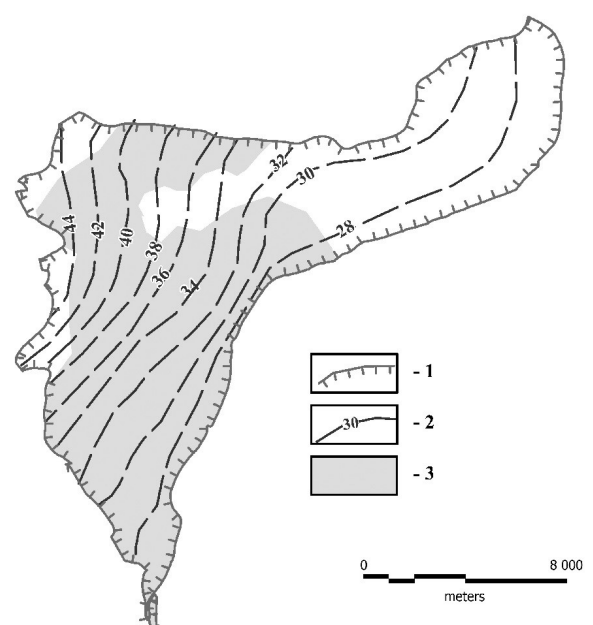

Фиг. 7. Карта с хидроизохипси на алувиалния водоносен хоризонт на Видинската крайдунавска низина (Benderev et al., 2014)

1 - граници на низината; 2 - хидроизохипси в абс. височини; 3 - участъци с плитко залягане на водното ниво $(<2 \mathrm{~m})$.

Fig. 7. Groundwater contour map of the alluvial aquifer in Vidin lowland (Benderev et al., 2014)

1 - lowland boundary; 2 - water table elevation, $\mathrm{m}$ asl; 3 - district with shallow groundwater level $(<2 \mathrm{~m})$

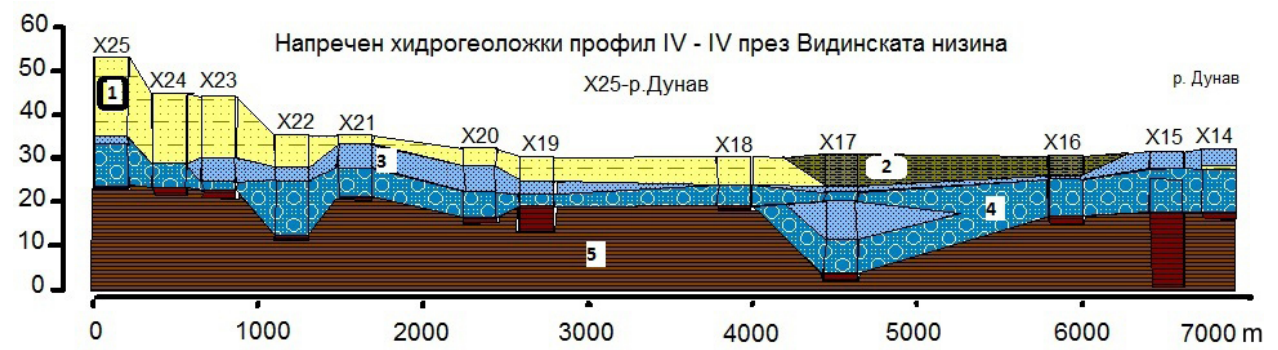

Фиг. 8. Напречен хидрогеоложки профил през Видинската низина при с. Слана бара (По данни от хидрогеоложките проучвания на „Водпроект”, 1958)

1 - глинести пясъци; 2 - песъчливи глини; 3 - пясъци; 4 - чакъли и пясъци; 5 - глини, водоупорни (Меот)

Fig. 8 Hydrogeological cross-section north of Slana Bara village (Data from Vodproekt, 1958)

1 - clayey sand; 2 - sandy clay; 3 - sand; 4 - gravel and sand; 5 - impermeable clay (Meot). 
Подложката на низината е изградена от миоценски глинести пластове:

- в района на с. Гомотарци и с. Кутово - Смирненска свита $\mathrm{smN1}{ }^{\mathrm{m}}$;

- в района на гр. Видин и с. Капитановци - долните слоеве на Арчарската свита $\operatorname{arN} 1^{\mathrm{p}}$;

- в района на гр. Видин и с. Дунавци - Криводолска свита krN1s.

Пиезометричното ниво в низината се диктува от водните стоежи на $p$. Дунав. В крайбрежните участьци годишната амплитуда на нивото достига 3-4 $\mathrm{m}$, а във вътрешността на низината е от порядъка на 1,5 m, като се контролира от отводнителна система. Нивото на подземната вода почти винаги се намира в горния слабо пропусклив слой, така че от хидродинамична гледна точка водоносният хоризонт се характеризира като полу-напорен.

Експлоатационните ресурси на подземните води се оценяват на 14 m³, като 13 $\mathrm{m}^{3} / \mathrm{s}$ от тях са привлекаеми водни количества от р. Дунав и $1 \mathrm{~m}^{3} / \mathrm{s}-$ инфилтрационно подхранване от валежи и приток от съседни водоносни хоризонти [БДДР]. Това водно количество няма връзка с вътрешния речен отток на страната и може да се разглежда като допълнителен потенциален експлоатационен воден ресурс.

По химически състав водата е хидрокарбонатно-сулфатно-натриево-калциева със сух остатьк $588 \mathrm{mg} / \mathrm{L}, \mathrm{pH}=7$ и обща твърдост $14,8^{\circ} \mathrm{dH}$ (фиг. 9). Превишение на стандарта за качество (СК) за никел е установено в мониторинговия пункт ШК1-ПС „КОС” гр. Видин.
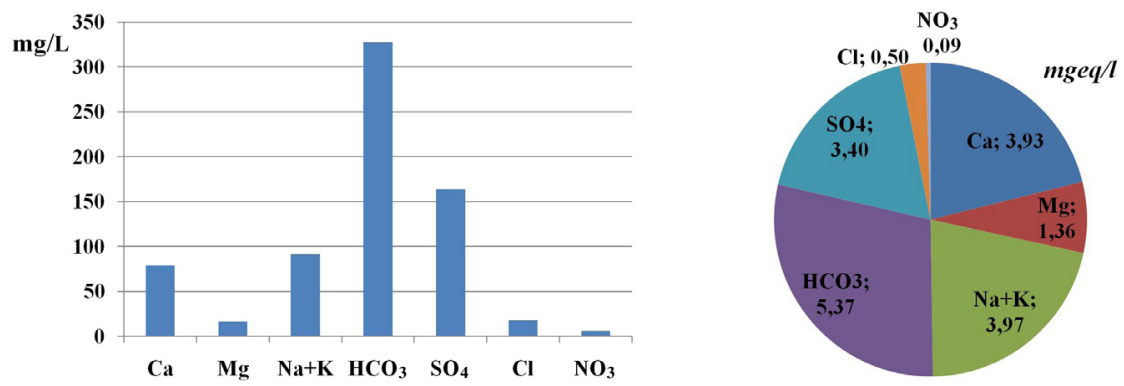

Фиг. 9. Химически състав на водата от алувиалния водоносен хоризонт на Видинската низина Fig. 9. Chemical composition of the alluvial aquifer in Vidin lowland

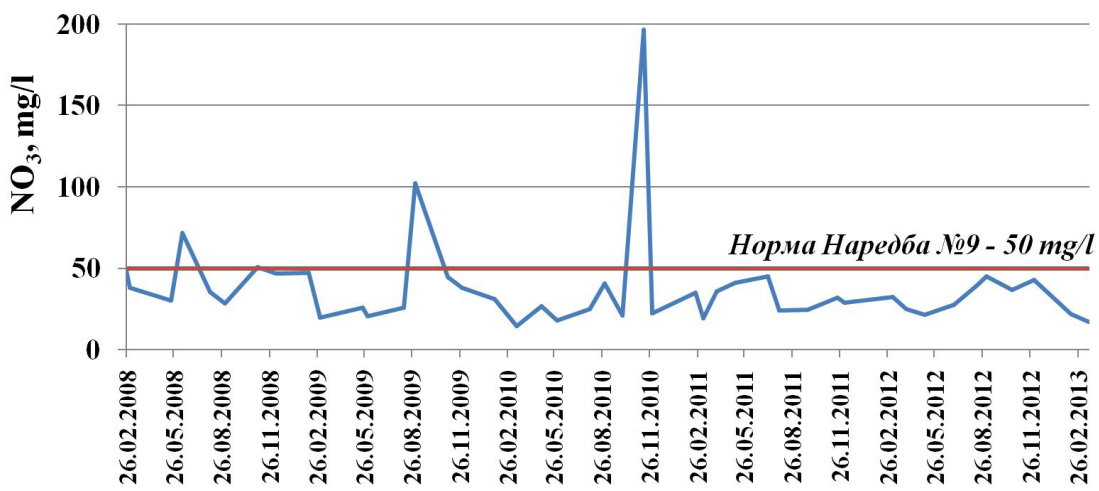

Фиг. 10. Изменение на съдържанието на нитрати в мониторингов пункт ШК 1- ПС «КОС» (Benderev et al., 2014)

Fig. 10. Variation of NO3 content in monitoring station "KOS" (Benderev et al., 2014) 
В южната част на низината, в района на с. Дунавци е установено наднормено съдържание на нитрати (фиг. 11).

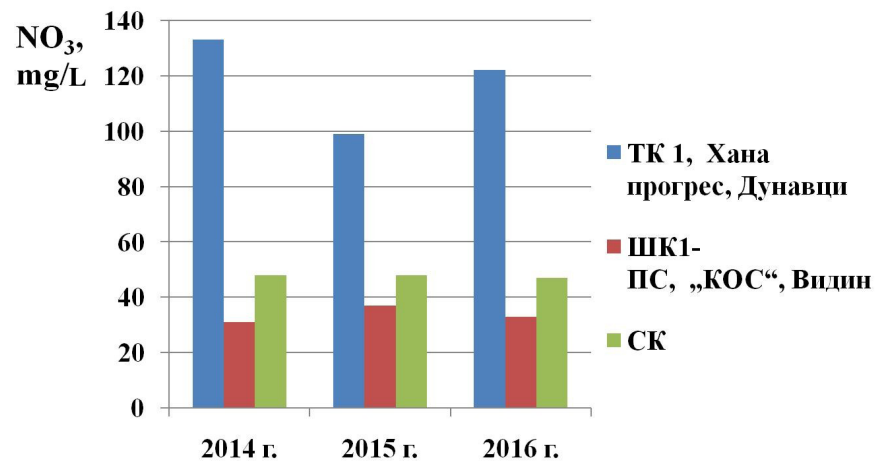

Фиг. 11. Съдържание на нитрати в подземните води на Видинската низина по данни на БДДР Fig.11. Nitrate content in groundwater of Vidin lowland (Data from Danube River Bassin Directorate)

Водоснабдяването на гр. Видин и още 20 населени места в общината (Гомотарци, Кошава, Сланотрън, Антимово, Кутово, Покрайна, Капитановци, Иново, Градец, Калина, Тияновци, Плакудер, Гъмзово, Майор Узуново, Винарово, Неговановци, Новоселци, Слана бара, Рупци и Акациево) се осъществява чрез ПС «Сланотрьн», която се състои от 4 кладенеца тип «Раней» с дълбочина 14,5 $\mathrm{m}$ и общ дебит $1100 \mathrm{~L} / \mathrm{s}$. През последните години работи основно кладенец № 1 , който е в състояние да подава необходимите количества вода за група „Видин“ с годишен добив $7300000 \mathrm{~m}^{3}$ или $230 \mathrm{~L} / \mathrm{s}$ питейна вода. При максимален дебит нивото в кладенеца се понижава с $1 \mathrm{~m}$. Останалите кладенци се включват само за поддържане на оборудването в изправност. Вторият водоизточник е разположен на $3 \mathrm{~km}$ северозападно от гр. Видин, в района „Кос“. Той се състои от 4 шахтови кладенеца с дълбочина 13 - 18 m, добиващи общо годишно водно количество от около $216000 \mathrm{~m}^{3}$ или $70 \mathrm{~L} / \mathrm{s}$. Качеството на водата и от двете водоснабдителни групи е добро и се прави само задължителната дезинфекция чрез хлориране (Temelkova, 2012). Старото водоснабдяване на гр. Видин е в района на с. Иново, където от 6 шахтови кладенеца са черпени $170 \mathrm{~L} / \mathrm{s}$. Във водовземната зона на бившия Стопански химически комбинат (завод за автогуми «Вида») са изградени 7 бр. кладенеца тип «Раней», през $600 \mathrm{~m}$, с дълбочина $15 \mathrm{~m}$ и общ проектен дебит $1700 \mathrm{~L} / \mathrm{s}$ при понижение на динамичното ниво 7 m, но при ниски води на p. Дунав дебитът намалява до $300-400 \mathrm{~L} / \mathrm{s}$. Един от тях се използва за битово водоснабдяване с минимален дебит $30-40 \mathrm{~L} / \mathrm{s}$ по време на маловодие. За подсилване на промишленото водоснабдяване, между ТЕЦ и корекцията на $\mathrm{p}$. Видбол са изградени 10 бр. тръбни кладенеца с общ дебит $200 \mathrm{~L} / \mathrm{s}$ и един "Раней” също 200 L/s. В най-южния край на низината - край с. Дунавци от 3 бр. шахтови кладенеца се добиват около $30 \mathrm{~L} / \mathrm{s}$ вода, която обаче е негодна за пиене поради повишено съдържание на нитрати, магнезий, флуор и обща твърдост $25-38^{\circ} \mathrm{dH}$.

\section{2. Плейстоценски водоносен комплекс}

Плейстоценските седименти във Видин-Кулския район в голяма степен са еродирани през холоцена. Само отделни петна от тях са останали в най- 
високите части на междуречните пространства. Те не са показани на картата, защото са маловажни и за да се откроят лежащите под тях основни водоносни тела (фиг. 1). Водоносният комплекс е запазен в релефната заравненост с надморска височина 55-60 m, разположена между низините Брегово, БалейКуделин и Новоселска. В основата на комплекса залягат споменатите по-горе плоскогорни чакъли с глинесто песъчлив запълнител $(5 \mathrm{~m})$. Съдейки по тяхното морфоложко положение и литоложкия им състав, те се идентифицират като долен Плейстоцен. Над тях следват червени глини $(4-5 \mathrm{~m})$, припокрити от еолични льосови наслаги, навявани през средния и горен Плейстоцен с дебелина до $25 \mathrm{~m}$. В плейстоценските седименти са врязани третата и четвърта надзаливна тераса на р. Тимок и р. Дунав. Водоносни са чакълните слоеве, като подземното водно ниво обикновено се установява в долнището на льоса.

Условията за подхранване на водоноса не са благоприятни. Равнинният релеф не способства за формиране на значителен повърхностен отток от валежите и снеготопенето. От друга страна, дебелата и силно пореста льосова покривка задържа голяма част от атмосферните води в горните приповърхностни слоеве и не позволява дълбока инфилтрация. Натрупаната през влажния сезон влага в почвения слой и зоната на аерация се изразходва за изпарение и транспирация през летния засушлив период. При наличието на близки съседни водообилни крайречни низини, този водоносен комплекс не е бил обект на задълбочени хидрогеоложки проучвания. Затова неговите филтрационни свойства не са добре изяснени. Изхождайки от общата хидрогеоложка обстановка, районът може да се характеризира като средно водоносен.

\section{2. Миоценски водоносни тела}

Миоценското развитие и стратиграфската подялба на Средиземноморието бяха усилено дискутирани през последните десетилетия в общоевропейски план. В решенията на шестия конгрес на Регионалния комитет по стратиграфия на Средиземноморския Неоген (1985) са приети три самостоятелни схеми на Неогена за отделните ясно обусловени палеогеографски области с различна история на развитие: Тетис, Централен и Източен Паратетис (Kojumdgieva, Popov, 1986). Нашите земи попадат в обсега на Източния Паратетис. Литостратиграфията на северозападната част на Мизийската платформа на наша територия е въведена в официална употреба през 1988 година от Коюмджиева и Попов (Kojumdgieva, Popov, 1988). Към миоценската серия се отнасят етажите: баденски, сарматски, меотски и понтски, а към плиоцена - дакски и левантски. В същата публикация са идентифицирани и съответните литостротиграфски свити. Тук ще характеризираме само онези от тях, които имат хидрогеоложко значение.

\section{1. Горно-понтски водоносен хоризонт (Арчарска свита)}

Горно-понтският водоносен хоризонт е широко застьпен в СЗ България. Най-добре той е развит в Ломската водонапорна система (Ломския артезиански басейн). Тук обаче, в Западно-Мизийската издигната водоносна система, от този хоризонт са запазени само отделни разпокъсани петна. В Понтския водоносен хоризонт се различават два слоя:

- Горен силно проницаем слой, състоящ се предимно от песъчливи материали. Той е развит е и запазен с най-голяма дебелина 100-120 m при с. Плакудер (Stoykov, 1960). Хоризонтът се дренира от малки извори в долината на р. Делейнска.

- Долен слабо проницаем, непродуктивен слой, състоящ се от мергелни, варовити и песъчливи глини. Той представлява водоупор на горно-понтския водоносен хоризонт.

Тектонската структурна единица “Видин-Пленишко издигане” е в подем през 
целия Плиоцен и Кватернер. Поради това, както отбелязахме, понтът в голямата си част е размит от ерозията, като са останали две по-големи петна върху темето на хълмовете от двете страни на р. Дилейнска. Закритата част на понта заляга под плейстоценските еолични наслаги и холоценските алувиални отложения на р. Дунав. Подходящ участьк за вододобив чрез сондажни кладенци се намира между селата Флорентин, Генерал Узуново и Гъмзово.

В подложката на Видинската низина, както и под плейстоценския водоносен комплекс при селата Кошава и Ново село е запазен само долният, слабо проницаем слой на понта (фиг. 1).

\section{2. Меотски водоупорен хоризонт (Смирненска свита)}

Меотските отложения са представени предимно от глинести материали с редки песъчливи прослойки и са известни като Смирненска свита. Те залягат под долния понт, който сыщо има глинест фациес. Този глинест комплекс служи за водоупор на горно-понтския водоносен хоризонт (фиг. 2 и 3 ).

\section{3. Сарматски водоносен хоризонт}

В сарматските седименти на С3 България, респективно в Западно Мизийската издигната хидрогеоложка система е формиран водоносен хоризонт, в който различаваме два етажа: горен карстово-пукнатинен и долен песъчливоваровиков, като между тях се разполагат водоупорни глинести слоеве с дебелина 10 до 30 m (Лехчевски клин на Криводолската свита).

- Горен карстово-пукнатинен етаж на сарматския водоносен хоризонт (fuN1s) (Фуренска свита)

Горният етаж на водоносния хоризонт е формиран във варовиковите пластове на Фуренската свита с дебелина от 20 до $40 \mathrm{~m}$. Водата в него е от карстовопукнатинен тип. Хоризонтът се разкрива на повърхността в централните части на района (фиг. 1). В северна посока той е припокрит от водоупорните глинести пластове на меота, от понтския водоносен хоризонт и кватернерните еолични отложения. На картата са показани като прозиращи и покритите части на хоризонта. Тектонското издигане на района, което продължава и понастоящем, е довело до дълбоко ерозионно врязване на реките и пълно разсичане на водоносния хоризонт по цялата му дебелина. Вертикалният мащаб на двата хидрогеоложки профила S-N и W-E е преувеличен 50-кратно, за да се покаже по-изразително разчлененият релеф и дрениращата роля на реките Видбол, Войнишка и Тополовец (фиг. 2 и 3). Подхранването на сарматския водоносен хоризонт е само от валежите. То е по-интензивно в откритите части на водоноса и по-затруднено - в покритите с льос участьци. Несъвършен долен водоупор представляват глинестите и песъчливо-глинести слоеве на т.нар. Лесурски клин на Криводолската свита, чиято дебелина е не повече от $10 \mathrm{~m}$.

Химическият състав на водата от горния, предимно варовиков сарматски водоносен хоризонт се проследява в мониторинговия пункт № 2/1 с. Грамада, карстови извори: «Езерото», «Дървеник», «Къдрица», «Пишура») от Националната опорна хидрогеоложка мрежа (HOXM) (фиг. 12). По осреднени данни от 4 опробвания през периода 1980-1991 г. (Tsankov et al., 1993) водата се характеризира като: прясна, хидрокарбонатно-калциева с обща минерализация $M=550 \mathrm{mg} / \mathrm{dm}^{3}$, средно твърда 5,439 meq/ $\mathrm{dm}^{3}$, годна за питейно-битово потребление.

- Долен порово-пукнатинен етаж на сарматския водоносен хоризонт (dmN1s) (Димовска свита)

Долният сарматски водоносен комплекс се разкрива в западните и южни части на района (фиг. 1). Той представлява смесица от песъчливи и варовикови отложения, като първите преобладават в долните отдели на задругата, а вторите - в по-високите нива. Дебелината на водоноса е от 20 до 70 m. На северо-изток 

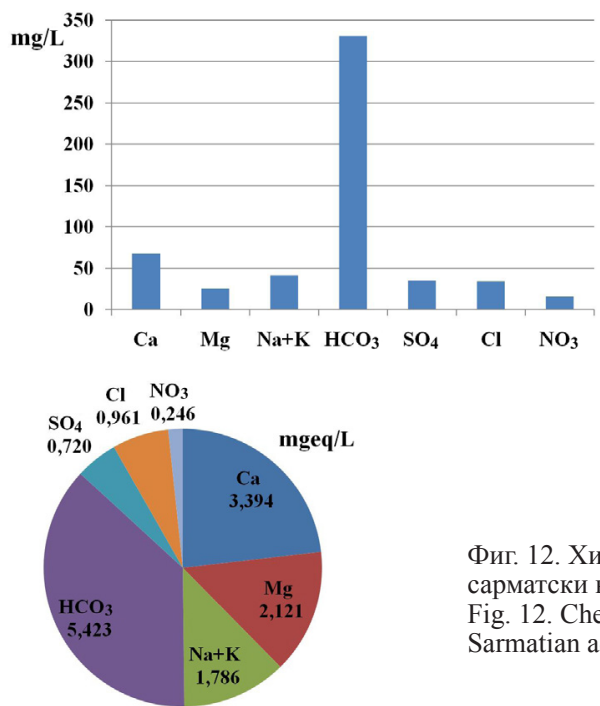

Фиг. 12. Химически състав на водата от горния сарматски водоносен хоризонт

Fig. 12. Chemical composition of water from the Upper Sarmatian aquifer

той е припокрит от 10 - 20 m слабо проницаеми глинести слоеве (Лесурски клин на Криводолската свита) и над тях е разположен горният сарматски водоносен хоризонт. Подхранването на подземните води се осъществява от валежите в откритата част на хоризонта. Дренирането се извършва директно в речните корита или чрез извори, излизащи по склоновете на речните долини. Такива са: 4 каптирани извора при с. Раброво (9 L/s); 3 каптирани извора за водоснабдяване на гр. Кула (3,2 L/s); район Грамада-Бояново - каптирани карстови извори с общ дебит $(60 \mathrm{~L} / \mathrm{s})$ и некаптирани $(20 \mathrm{~L} / \mathrm{s})$; при с. Цар Петрово (5-6 L/s); с. Буковец $(13 \mathrm{~L} / \mathrm{s})$; с. Войница $(8 \mathrm{~L} / \mathrm{s})$, с. Макреш "Хайдушка чешма" (5 L/s) и др. Системни режимни наблюдения се извършват за дебита на каптиран извор № 1 (6 km СИ от гр. Грамада) и каптиран извор № 120 (6 km ЮИ от гр. Кула) по старата номерация на опорната хидрогеоложка мрежа. Л. Василева (Vasileva, 1977) анализирайки мониторинговите данни през периода 1959 - 1974 г. установява плавно изменение на дебитите около $Q=6 \mathrm{~L} / \mathrm{s}$ за извор № 120 и $Q=30 \mathrm{~L} / \mathrm{s}$ за извор № 1 . Коефициентите за изменчивост на дебитити $\left(Q_{\min } / Q_{\max }\right)$ са в границите 0,35 до 0,85 за извора при гр. Кула и 0,24 до 0,85 за извора при гр. Грамада, които ги характеризират като извори с променлив дебит.

Естествените ресурси на водоносния хоризонт са определени по метода на разчленяване на речните ходографи. Водосборните области на реките Тополовец и Войнишка почти изцяло попадат в сарматски седименти. Това дава основание подземното подхранване на реките да се счита за една реалистична оценка за естествените ресурси на водоносния хоризонт. По данни от генетичното разчленяване на ходографите на водните количества на р. Тополовец за период от 21 години и за р. Войника - 13 години е получен осреднен модул на подземния отток $1,3 \mathrm{~L} / \mathrm{s} / \mathrm{km}^{2}$ или валежно подхранване на подземните води от около $40 \mathrm{~mm} /$ year.

Карстово-пукнатинният характер на горния водоносен слой предопределя нееднородността на филтрационните му свойства. Така при с. Пешаково и с. Бяла Рада от водочерпене е получен $K=0,01 \mathrm{~m} / \mathrm{d}$, при с. Бойница $1,33 \mathrm{~m} / \mathrm{d}$. Филтрационните свойства на долния сарматски слой също са ниски, поради нееднородния му литоложки състав $(K=0,1-2,5 \mathrm{~m} / \mathrm{d}$ при гр. Кула). Сондажни тръбни кладенци в сарматские водонос дават дебити $1-3 \mathrm{~L} / \mathrm{s}$. 
Химическият състав на водата се проследява в мониторинговия пункт № 1 / 120 гр. Кула, каптиран извор „Мехмеда” от Националната опорна хидрогеоложка мрежа (фиг. 13). По статистически обработени данни от 41 опробвания, през периода от 1980 - 1991 г. (Tsankov et al., 1993) водата се характеризира като: прясна, хидрокарбонатно-калциева с обща минерализация $M=660 \mathrm{mg} / \mathrm{dm}^{3}, \mathrm{pH}=$ 6,8, средно твърда $\left(7,579 \mathrm{meq} / \mathrm{dm}^{3}\right)$, годна за питейно битови цели.

Северно и източно от показаните очертания на сарматските водоносни пластове, фациесът се променя и преминава в глинестите материали на непродуктивното водоупорно тяло - Криводолската свита (фиг. 1).
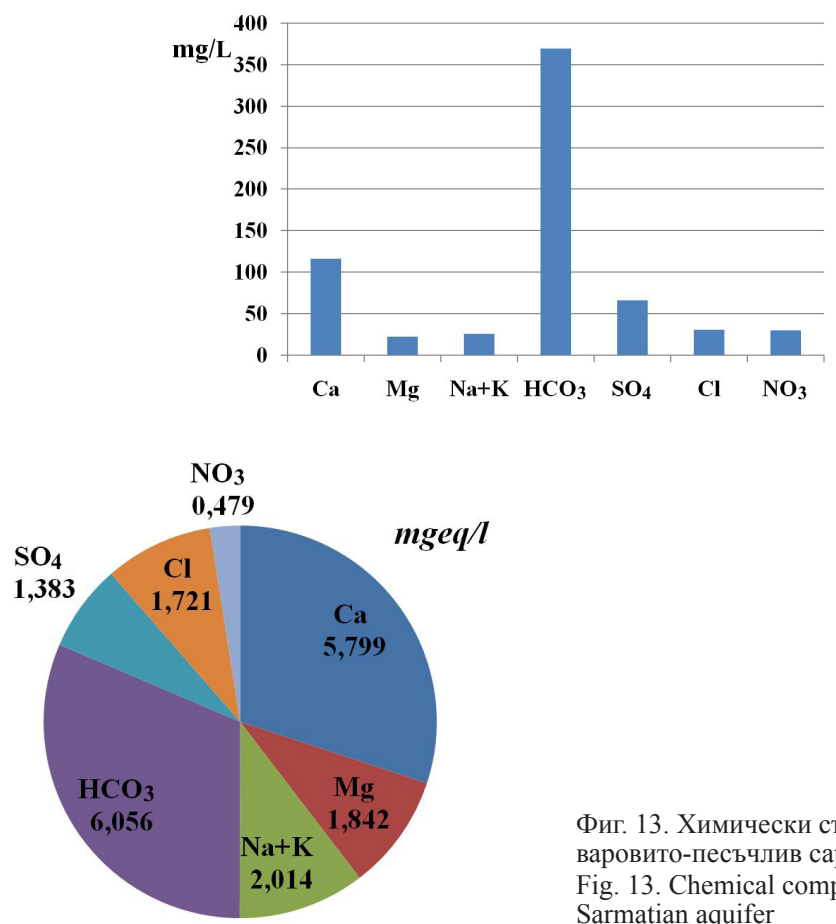

Фиг. 13. Химически състав на водата от долния варовито-песъчлив сарматски водоносен хоризонт Fig. 13. Chemical composition of water from the Lower Sarmatian aquifer

\section{3. Дълбоки водоносни хоризонти и комплекси}

В района на гр. Видин сарматските отложения се срещат в сондажи на дълбочина под $180-200 \mathrm{~m}$. Оскъдната подземна вода, доколкото я има в тези непродуктивни сарматски седименти, е силно минерализирана $(2,3-16 \mathrm{~g} / \mathrm{L})$ (Yovchev, Ryzhova, 1962) и не представлява интерес за водоснабдяване. В района на гипсовото находище при с. Кошава тортонската вода е хлор-натриева с температура до $42^{\circ} \mathrm{C}$ и с обща минерализация от 10 до $129 \mathrm{~g} / \mathrm{L}$. В района на с. Гомотарци дълбоки нефто-проучвателни сондажи са преминали и късно- кредни водоупорни мергелни пластове.

В още по- дълбоките недра на Мизийската платформа, в условията на забавен или липсващ водообмен, интерес представлява древно окарстения горноюрскодолнокреден водоносен хоризонт, съдържащ силно минерализирани води (>50 $\mathrm{g} / \mathrm{L})$ хлоридно-натриеви води с температура $35-41^{\circ} \mathrm{C}$ и значително съдържание

${ }^{2}$ Менахемова, Р., И. Станев, С. Трашлиев. 1960. Доклад за детайлните геоложки проучвания на гипсовото ноходище при с. Сланотрън и с. Кошава, Видинско през 1959 г., УГП, Геофонд. 
на бром и йод (Менахемова и др., 1960ф 2 ; Stanev, 1970). Например, водата от сондаж край с. Кошава от дълбочина 740 m има състав по формулата на Курлов:

$$
\mathrm{M} \quad 54,9 \frac{\mathrm{Cl}-96}{\mathrm{Na}-81 ; \mathrm{Ca}-12}
$$

и съдържание на I $(7,8) ; \mathrm{Br}(87,3) ; \mathrm{B}(25)$ в $(\mathrm{mg} / \mathrm{L})$ т.е. тя в същност представлява натриево-хлориден разсол (Yovchev, Ryzhova, 1962).

През 1968 г, в близост до с. Сланотрън, на 30-40 m зад дигата на р. Дунав е прокаран проучвателен сондаж C-3, който е давал на самоизлив $5 \mathrm{~L} / \mathrm{s}$ силно минерализирана вода. От нея, в инсталация, разположена на територията на гипсова мина „Кошава”, е преваряван концентрат за производството на известната паста за зъби „Мери”. На мястото е имало и сграден фонд - бани, басейни, съблекални, стадион, които към момента са полуразрушени и неизползваеми. През 1986 г. сондажът е тампониран с бетон, за да се прекрати смесването на минерализираната вода с прясната подземна вода от терасата на р. Дунав, с която се водоснабдява гр. Видин, чрез кладенеци - тип Раней.

\section{Заключение}

- Западно-Мизийската издигната хидрогеоложка система е идентифицирана като отделна структурна единица със специфични условия и функционалност, отличаващи я от съседния Ломски артезиански басейн.

- В територията, определяна досега като Брегово-Новоселска крайдунавска низина, в същност са формирани четири отделни хидрогеоложки единици: две крайбрежни низини на р. Тимок - Бреговска и Балей-Куделин и една крайдунавска - Новоселската, включително и разположения между тях плейстоценски водоносен комплекс.

- $\quad$ Тази част от Мизийската платформа, след края на Миоцена е подложена на интензивно издигане, вследствие на което всички водоносни хоризонти са дълбоко ерозирани и до голяма степен са дренирани в речните долини.

- Най-водообилен в системата е алувиалният водоносен хоризонт, развит в крайдунавските Видинска и Новоселска низина. В тях проблеми могат да възникват по отношение на качеството на водите, но не и по отношение на количествата.

- Сарматският водоносен хоризонт е развит в песъчливо-варовит фациес. Той е втори по значимост в разглежданата водоносна система. Водите му се използват за водоснабдяване предимно чрез каптиране на извори.

- Подземните води на Западно-Мизийската хидрогеоложка система са главният източник за питейно-битово водоснабдяване във Видинския район. Необходим е строг контрол за предпазването им от индустриални и селскостопански замърсявания.

\section{Литература}

\section{References}

Antonov, H., N. Boyadjiev, D. Danchev, I. Iliev, P. Petrov, N. Plotnikov. 1962. Hydrogeological subdivision of Bulgaria. Works on Geol. Bulg. Ser. Eng. Geol. and Hydrogeol., 1, 1-212, (in Bulgarian, with English abstract).

Antonov, H., D. Danchev. 1980. Groundwater in the Republic of Bulgaria. Sofia, Technika, 360 p. (in Bulgarian).

Baltakov, G. 2005. The Danube valley between Dgerdap gorge and Black Sea during the last 300000 years. http://www.bulgari-istoria-2010.com/booksBG/G Batlakov_Dunav.pdf, 13 p. (in Bulgarian, with English abstract). 
Benderev, A., M. Krastanov, N. Dobrev. 2013. Status and problems of the use of groundwater for drinking purposes in Danube lowlands (the example of the Vidin lowland). 13th International Multidisciplinary Scientific GeoConference of Modern Management of Mine Producing, Geology and Environmental Protection (SGEM 2013) Albena, Bulgaria, Book 1, Vol. 2, 379-387.

Benderev, A., M. Krastanov, B. Berov. 2014. Assessment of the main factors which influence the vulnerability of groundwater in the Danubian lowlands. Problems of Geography, 2014, 1-2, 87-99 (in Bulgarian, with English abstract).

Evlogiev, J. 1988. The The Eopleistocene in Danube North Bulgaria and its boundary with the Neogene. Rev. Bulg. Geol. Soc., 49, 2, 37-44 (in Bulgarian, with English abstract).

Evlogiev, J. 2006. The Pleistocene and Holocene in the Danube Plain. Unpublished D. Sci. Thesis. Sofia, Geol. Inst., Bulg. Acad. Sci., 80 p. (in Bulgarian).

Filipov, L., A. Decheva, E. Kojumdgieva, N. Popov, Ts. Tsankov. 1992. Geological Map of Bulgaria on Scale 1:100 000. Vidin Map Sheet. Geology and Mineral Resources Committee, Enterprise of Geophysical Survey and Geological Mapping.

Filipov, L., E. Kojumdgieva, N. Popov. 1992. Geological Map of Bulgaria on Scale 1:100 000. Bregovo and Băileşti Map Sheet. Geology and Mineral Resources Committee, Enterprise of Geophysical Survey and Geological Mapping.

Jaranoff, D. 1961. La limite Pliocene - Pleistocene et la stratigraphie du Quaternaire en Bulgarie. Rev. Bulg. Geol. Soc., 22,2, 187-203 (in Bulgarian with French abstract).

Kojumdgieva, E., N. Popov. 1986. Stratigraphy and correlation of the Neogene in the Mediterranean region, solutions and discussions. Rev. Bulg. Geol. Soc., 47, 3, 124-126 (in Bulgarian).

Kojumdgieva, E., N. Popov. 1988. Lithostratigraphy of Neogene sediments in NW Bulgaria. Paleontology, Stratigraphy and Lithology, 25, 3-26 (in Bulgarian).

Spasov, V. 1966. Natural resources of ground waters in the zone of active water exchange in Northern Bulgaria. Works on Geol. Bulg. Ser. Eng. Geol. and Hydrogeol., 5, 71-90 (in Bulgarian, with English abstract).

Stanev, I. 1970. Ancient and modern karst in Upper Jurassic-Lower Cretaceous aquifer in Northern Bulgaria. Rev. Bulg. Geol. Soc., 31, 2, 241-249 (in Bulgarian).

Stoykov, S. 1960. The Pliocene in Vidin and Kula region. Rev. Bulg. Geol. Soc., 21, 1, 28-35 (in Bulgarian).

Temelkova, M. 2012. Status, problems and perspectives of the water systems in municipalities along the Danube in Northwestern Bulgaria. Problems of Geography, 2012, 3-4, 138-148 (in Bulgarian, with English abstract).

Tsankov, Ts., M. Machkova, D. Dimitrov, A. Lichev, I. Milushev, K. Burmov. 1993. Hydrochemical reference book of groundwater in the Republic of Bulgaria 1980 1991. 119 p. (in Bulgarian).

Vasileva, L. 1977. Regime and prognosis of the springs flow draining the Sarmatian aquifer from the region of Kula. Hydrology and meteorology, 5, 55-63 (in Bulgarian).

Yovchev, R., E. Ryzhova. 1962. Groundwater in Northern Bulgaria. Main Directorate for Geology and Subsoil Protection, Sofia, 222 p. (in Russian).

Постьпила: 14.02 .2020

Приета: 27.03.2020
Received: 14 February 2020 Accepted: 27 March 2020 